\title{
Mixed Malarial Infection with Pancytopenia in a Child with Acute Lymphoblastic Leukemia: An Unusual Presentation
}

Sir,

I have read with interest the case report by Ramesh et al. on mixed malarial infection associated with pancytopenia in a child with acute lymphoblastic leukemia (ALL). ${ }^{[1]}$ Two plausible explanations could be addressed to explain that association. The first is that it is an incidental association. The second is that it is possibly an etiological association. It is noteworthy that severe childhood infections can occasionally be accompanied by bone marrow suppression and that it is unusual for infection-induced marrow aplasia to evolve into acute leukemia. ${ }^{[2]}$ I presume that the observed pancytopenia in the case in question was probably the result of malarial parasite acting in rhythm with the failing bone marrow and malarial parasite is possibly one of many factors able of initiating the onset of pre-ALL. Molecular studies are needed to determine the exact mechanism.

Second, India is endemic for malaria with unstable transmission inhibiting the development of immunity and predisposing all age groups to the disease. ${ }^{[3]}$ I presume that the case in question sends an important message to the practicing clinicians in malaria-endemic areas to consider underlying malignancy in malaria patients if pancytopenia is refractory despite eradication of malarial infection.

Financial support and sponsorship

Nil.

\section{Conflicts of interest}

There are no conflicts of interest.

Mahmood Dhahir Al-Mendalawi

\author{
Department of Paediatrics, Al-Kindy College of Medicine, \\ University of Baghdad, Baghdad, Iraq \\ Address for correspondence: \\ Prof. Mahmood Dhahir Al-Mendalawi, \\ P.O.Box 55302, Baghdad Post Office, Baghdad, Iraq. \\ E-mail: mdalmendalawi@yahoo.com
}

\section{References}

1. Ramesh V, Venkata NM, Sankar J. Mixed malarial infection with pancytopenia in a child with acute lymphoblastic leukemia: An unusual presentation. Indian J Med Paediatr Oncol 2017;38:92.

2. Rajendran A, Trehan A, Ahluwalia J, Marwaha RK. Severe systemic infection masking underlying childhood leukemia. Indian J Hematol Blood Transfus 2013;29:167-70.

3. Basu S, Sahi PK. Malaria: An update. Indian J Pediatr 2017;84:521-8.

This is an open access journal, and articles are distributed under the terms of the Creative Commons Attribution-NonCommercial-ShareAlike 4.0 License, which allows others to remix, tweak, and build upon the work non-commercially, as long as appropriate credit is given and the new creations are licensed under the identical terms.

\begin{tabular}{|l|l|}
\hline \multicolumn{2}{|c|}{ Access this article online } \\
\hline Quick Response Code: & Website: \\
\hline & www.jmmo.org \\
\cline { 2 - 2 } & Dol: \\
\hline
\end{tabular}

How to cite this article: Al-Mendalawi MD. Mixed malarial infection with pancytopenia in a child with acute lymphoblastic leukemia: An unusual presentation. Indian J Med Paediatr Oncol 2018;39:551.

○) 2018 Indian Journal of Medical and Paediatric Oncology | Published by Wolters Kluwer - Medknow 